\title{
Jeitos de corpo: cor/raça, gênero, sexualidade e sociabilidade juvenil no centro de São Paulo*
}

\author{
Júlio Assis Simões** \\ Isadora Lins França ${ }^{* * * *}$ \\ Marcio Macedo****
}

\section{Resumo}

Neste texto discutimos resultados de partes da pesquisa realizada em São Paulo entre 2006 e 2008, dentro do projeto mais amplo, "Relations among 'race', sexuality and gender in different local and national contexts". Comparamos espaços de sociabilidade juvenil reconhecidos como homo e heterossexuais na região do centro histórico da cidade, tendo por fio condutor os modos como marcadores de diferença referidos a cor/raça, classe, gênero $e$ sexualidade operam para classificar frequentadores, numa lógica de produção de sujeitos desejáveis (ou não) e de preferências de parcerias afetivo-sexuais; assim como para ordenar padrões de interação Refletimos sobre os modos e condições em que essas diferenças - que informam e constroem representações de hierarquia e discriminação - são agenciadas por determinados sujeitos em campos específicos de relações, tendo em vista suas trajetórias sociais.

Palavras-chave: Diferença, Cor/Raça, Gênero, Sexualidade, Estilo.

\footnotetext{
* Recebido para publicação em agosto de 2010, aceito em setembro de 2010.

** Professor do Departamento de Antropologia da Universidade de São Paulo. juliosimoes@usp.br

**** Doutora em Ciências Sociais, Pesquisadora Colaboradora do Núcleo de Estudos de Gênero - Pagu/Unicamp. isadora.lins@uol.com.br

*****D Doutorando em Sociologia, The New School of Social Research, Bolsista IFP da Fundação Ford. mjmacedo73@gmail.com
}

cadernos pagu (35), julho-dezembro de 2010:37-78. 
Jeitos de corpo

Manners and Bodies: Color/Race, Gender, Sexuality and Youthful

Sociability in the Historic Downtown of São Paulo

\begin{abstract}
In this article, we discuss the results of ethnographic research undertaken in areas with concentrated recreational venues frequented by diverse youth groups (homo- and heterosexual) in the Historic Downtown of São Paulo. This material is part of the larger "Relationships between race, gender and sexuality in different national and local contexts" research initiative. We consider how markers of difference associated with color/race, class, gender and sexuality operate not only to classify the young men and women who engage in erotic sociability in the places we investigated - producing (un)desirable subjects and indicating affective-sexual preferences - but also work to order patterns of social interaction. We reflect on what ways and under what conditions differences (which can, of course, inform and construct hierarchical and discriminatory relationships) are employed by certain subjects in specific relational fields, given certain social trajectories.
\end{abstract}

Key Words: Difference, Color/Race, Gender, Sexuality, Style. 
Neste texto discutimos resultados de duas partes da pesquisa realizada na cidade de São Paulo entre 2006 e 2008, dentro do projeto mais amplo "Relations among 'race', sexuality and gender in different local and national contexts". Uma parte trata das sociabilidades homoeróticas na área em torno da avenida Dr. Vieira de Carvalho, centro histórico da cidade; e a outra se refere ao trabalho de campo conduzido no clube Sambarylove, um conhecido baile black marcadamente heterossexual e localizado na região da Bela Vista, bem próximo ao centro histórico. ${ }^{1}$ A partir desse material, interessa-nos pensar os modos como marcadores de diferença referidos a cor/raça, classe, gênero e sexualidade operam não apenas para classificar os frequentadores desses lugares, numa lógica de produção de sujeitos desejáveis (ou não) e de preferências de parcerias afetivo-sexuais; mas também para ordenar padrões de interação e evidenciar campos de possibilidades e de ações. Na economia erótica que informa esses lugares de sociabilidade juvenil, tratamos de focalizar narrativas $e$ experiências colhidas no trabalho de campo como operações discursivas $^{2}$ que colaboraram na construção de uma espécie de estrutura de atitudes, referências e expectativas acerca das relações entre cor/raça, gênero e erotismo.

1 A pesquisa sobre sociabilidade homoerótica na região da Avenida Dr. Vieira de Carvalho teve como coordenadores de campo Isadora Lins França e Luiz Henrique Passador. Os dados aqui apresentados incluem também partes do material coletado para as teses de doutorado desenvolvidas por Regina Facchini (2008) e por Isadora Lins França (2010), no Programa do Doutorado em Ciências Sociais, área Estudos de Gênero, do IFCH/Unicamp, as quais foram orientadas, respectivamente, por Maria Filomena Gregori e por Júlio Assis Simões. O trabalho de campo no Sambarylove foi coordenado por Márcio Macedo e conduzido por Larissa Zanotto Costardi e Alice Vieira.

2 Essas formulações inspiram-se livremente na discussão de Said sobre o "orientalismo" (Said, 2001), porém dando ênfase às ambivalências presentes nas operações discursivas envolvendo cor/raça, classe, gênero e sexualidade, de modo a problematizar sua interpretação como sinais inequívocos de posições de dominação e subordinação. Para uma crítica dos supostos de dominação e subordinação presentes na abordagem de Said, ver Bhabha, 1998. 
Jeitos de corpo

Investigar esse "horizonte imaginativo" (Crapanzano, 2004), seguindo uma estratégia de comparar universos reconhecidos como homo e heterossexuais, permite-nos iluminar o lugar que a diferença (Brah, 2006) ocupa nas relações que envolvem afeto $e$ desejo. Procuramos refletir sobre os modos e condições em que essas diferenças, que informam e constroem representações de hierarquia e discriminação, são agenciadas por determinados sujeitos em campos específicos de relações. ${ }^{3}$

Partimos da visão de que categorias associadas a cor/raça, gênero e sexualidade são produções culturais e históricas, articuladas em sistemas classificatórios que envolvem dimensões semânticas e pragmáticas (Crapanzano, 2001). A marcação da diferença é um componente-chave de qualquer sistema classificatório. Desse modo, pessoas, objetos e comportamentos ganham sentido - vale dizer, são socialmente produzidos - por meio da atribuição de diferentes posições em um sistema classificatório. É importante distinguir entre a lógica interna que articula categorias em sistemas classificatórios e os processos de classificação propriamente ditos. ${ }^{4}$ As categorias definem-se umas em relação às outras, além de atravessarem e circularem por diferentes relações; assim, por exemplo, categorias referentes a

3 Deve estar claro, desde já, que este texto é fruto de elaboração e discussão coletiva e que sua autoria ultrapassa os que aqui aparecem creditados como autores. Além da pesquisa comparativa internacional que lhe deu origem, esta reflexão se beneficia de um amplo processo que colocou para circular um capital simbólico específico relativo a sexualidade, raça e direitos humanos, promovendo diálogos e encontros antes pouco comuns ou inexistentes, para o qual contribuíram instituições: Centro Latino-Americano em Sexualidade e Direitos Humanos - CLAM/UERJ (www.clam.org.br), Núcleo de Estudos de Gênero - Pagu/Unicamp (www.pagu.unicamp.br) e o recém-criado Núcleo de Estudos dos Marcadores da Diferença da USP (http://numas-usp.blogspot.com).

4 Agradecemos a Peter Fry por ter-nos chamado a atenção para esse ponto. A distinção entre taxonomias e classificações pode ser correlacionada à distinção complementar entre "interpelação" e "reconhecimento", que perpassa tantas formulações sobre ideologia e produção discursiva em diferentes tradições inspiradas criticamente no estruturalismo. Ver, a propósito, Stuart Hall, 2000. 
sexualidade e gênero inscrevem-se com frequência em matrizes de cor/raça, e vice-versa, tornando-se muitas vezes uma linguagem poderosa para expressar hierarquias e desigualdades sociais mais amplas. A classificação é o processo pelo qual indivíduos tornamse sujeitos e atores sociais, apropriando-se de - ou sendo levados a se reconhecer em - determinadas identidades; o que, por sua vez, lhes abre determinados cursos de ação.

Acreditamos que investigar a relação entre os atores sociais $e$ os sistemas classificatórios referentes a cor/raça, gênero $e$ sexualidade, no campo dos relacionamentos eróticos e afetivos, pode contribuir também para iluminar deslocamentos e mudanças nos sistemas classificatórios. Sob esse aspecto, é possível delinear movimentos contrastantes que se verificam nas taxonomias de sexualidade e de cor/raça operantes no Brasil contemporâneo. Os eixos classificatórios relacionados à sexualidade tendem a apresentar uma crescente complexidade terminológica. A hierarquia de gênero, articulada a partir da oposição masculinidade/atividade sexual versus feminilidade/passividade sexual, que englobaria de forma sistemática todas as identidades sexuais em termos de oposições bipolares entre "machos" $e$ "fêmeas", "homens" e "bichas", ou "sapatões" e "mulheres", tem convivido com uma proliferação de categorias e identidades sexuais - tais como "entendidos", "gays", "homossexuais" "travestis", "transexuais", "queers", "sem rótulos" -, cada qual acompanhada de modulações de performances de gênero. ${ }^{5}$ Nos eixos classificatórios de cor/raça, em contrapartida, a tendência parece ser um movimento que simplifica a variedade de categorias do modo múltiplo - como "moreno", "marrom bombom", "preto

5 A formulação clássica do sistema classificatório da homossexualidade entre homens baseada no gênero e na posição esperada no ato sexual no Brasil é o modelo hierárquico-popular de Fry (1982), que o contrapunha ao modelo igualitário-moderno usado inicialmente pelos gays de classe média intelectualizada das metrópoles, parte dos quais veio alimentar o emergente movimento político homossexual brasileiro no final dos anos 1970. Para uma discussão crítica desse modelo, ver Carrara e Simões (2007). 
Jeitos de corpo

mesmo", "branco mesmo", "canela", "castanho", entre outros por meio do uso situacional crescente do modo bipolar "negros"/"brancos", no qual eventualmente emerge a categoria intermediária "pardo". 6

Esses diferentes deslocamentos são, em boa parte, influenciados pela ação do movimento homossexual $e$ do movimento negro, bem como pelo desenvolvimento de diferentes modalidades de políticas voltadas a esses segmentos. Um aspecto notável é que a aplicação das categorias classificatórias relacionadas à homossexualidade e à cor/raça permanece altamente dependente de contingências e contextos. Nesse sentido, conhecer as lógicas das classificações locais e a forma como essas classificações informam e conformam correlações de força diferenciadas e situacionais é relevante para acompanhar um longo percurso de continuidades e mudanças sociais e políticas às quais as categorias cor/raça, gênero e sexualidade estão, de fato, articuladas.

No imaginário da construção da nação, no pensamento social brasileiro do final do século XIX até a metade do século XX, a sexualidade e a miscigenação ocuparam lugar privilegiado, juntamente com uma peculiar celebração do desejo inter-racial. Narrativas literárias, históricas e sociológicas da miscigenação brasileira produzidas àquela época tenderam a realçar o par assimétrico formado por homens brancos e mulheres (mas também "moleques"7) negras e mestiças. Essas relações foram

6 Esta caracterização dos modos de classificação de cor/raça no Brasil como múltiplo e bipolar, considerando os usos militantes e populares deste último, segue a elaboração de Fry (2005). Ver também Schwarcz (2000) e Moutinho (2004).

7 Em Casa-grande \& senzala, Gilberto Freyre equiparou o moleque, como "paciente do senhor moço entre as grandes famílias escravocratas do Brasil", ao do escravo púbere escolhido para companheiro do rapaz aristocrata no Império Romano, observando que "através da submissão do moleque, seu companheiro de brinquedos e expressivamente chamado de leva-pancadas, iniciou-se muitas vezes o menino branco no amor físico" (Freyre, 2000:122). 
configuradas como opostas à conjugalidade convencional: seriam uniões informais e verticais, atravessadas por intenso erotismo, mas também pela desigualdade entre os parceiros, acentuadas pelos marcadores de gênero e pelas relações de subordinação que remetiam à escravidão. Nessas narrativas, que combinam lubricidade, dominação $e$ identidade nacional, homens negros $e$ mestiços eram personagens secundários ou esquecidos; os raros retratos literários focalizando relacionamentos entre um homem negro e uma mulher branca adquirem frequentemente o tom de tragédia (Moutinho, 2004). É a tragédia que prevalece também naquele que hoje é saudado como o primeiro romance gay brasileiro, Bom-Crioulo, de Adolfo Caminha, publicado em 1895, no qual figura um par homossexual formado por dois marinheiros, um adulto negro e um adolescente branco.

Hoje em dia, em contrapartida, são correntes no imaginário brasileiro representações sobre sensualidade $e$ lubricidade atribuída aos homens negros e mestiços, valorizados segundo metáforas de volume, virilidade e desempenho sexual. Ainda assim, persiste a percepção social de que relacionamentos interraciais giram principalmente em torno do erotismo e implicam transações entre parceiros desiguais, marcadas por cálculo e interesse - seja para obter vantagens materiais ou prestígio social (da perspectiva dos homens negros e mestiços), seja para exercer controle sobre um parceiro socialmente mais fraco (da perspectiva de mulheres $e$ homens brancos que buscam homens negros $e$ mestiços como parceiros). ${ }^{8}$

Tensões relativas à oposição entre erotismo e conjugalidade são particularmente acentuadas no que diz respeito aos relacionamentos homossexuais. ${ }^{9}$ Um ponto de vista sociológico firmemente estabelecido considera que o estigma da homossexualidade faz com que entre os homens, especialmente, o

\footnotetext{
8 Moutinho (2004) discute mais amplamente esses pontos.

9 Agradecemos a Sergio Carrara por ter-nos chamado a atenção para esse ponto.
} 
Jeitos de corpo

homoerotismo se mantenha descolado da afetividade, dando lugar a relacionamentos múltiplos e fugazes, segundo uma linguagem de olhares e gestos, com pouca conversa e muita ação. ${ }^{10}$ Por serem contrapostos à conjugalidade convencional $e$, ao mesmo tempo, disporem de territórios de sociabilidade próprios e em expansão, os relacionamentos homossexuais entre homens abririam também uma possibilidade frequente de transgredir barreiras sociais de idade, cor/raça e classe. $\mathrm{Na}$ verdade, essas transgressões são consideradas, muitas vezes, o combustível fundamental do desejo homoerótico.

Atualmente, a ideia de uma existência mais respeitável "fora do armário", incluindo projetos de conjugalidade, é uma possibilidade plausível para muitos jovens (e nem tão jovens assim) homossexuais, pelo menos nas grandes cidades brasileiras. Os valores e representações associados ao homoerotismo, com suas hierarquias, "tensores libidinais" $e$ "fugas desejantes" (Perlongher, 2008) ${ }^{11}$ - que marcaram a primeira ostensiva "saída do armário" dos homossexuais no Brasil no final dos anos 1970, cujo palco privilegiado, em São Paulo, foi a região da avenida Vieira de Carvalho e Largo do Arouche, no centro histórico - convivem agora com demandas políticas e projetos de vida que contemplam

\footnotetext{
${ }^{10}$ Esse argumento é claramente exposto por Pollak (1985). Ellingson et alii (2004) argumentam que a organização do mercado homoerótico entre homens é sobretudo "transacional", isto é, voltada à busca de encontros sexuais transitórios, de duração breve, orientados pelas expectativas de aparência física e pela frequência a lugares reconhecidos como pontos de encontro de parceiros potenciais. "Transacional" aqui se opõe a "relacional", categoria usada para referir à busca por estabelecer parcerias duráveis.

${ }^{11} \mathrm{Em}$ importante pesquisa realizada nos anos 1980, sobre as relações entre homens mais velhos e garotos de programa no centro da cidade de São Paulo, Perlongher (2008) descreveu um complexo sistema de atribuição de posições e valores no mercado homossexual de desejos e afetos de acordo com marcadores de gênero, idade, classe e cor/raça. Perlongher chamou esses marcadores de "tensores libidinais", que operariam tanto como veículos de atribuições classificatórias quanto como estimuladores do que ele, seguindo Deleuze e Guattari (1976), chamava de "fugas desejantes".
} 
conjugalidade e parentalidade homossexuais, que se tornaram bandeiras do movimento LGBT. No presente, a cena homossexual na cidade de São Paulo estampa as marcas da visibilidade e da inclusão, com a expansão e diversificação das expressões identitárias amparadas pela difusão de mercado segmentado voltado à homossexualidade e pelo modelo de ativismo bemsucedido e consagrado na Parada do Orgulho LGBT. Porém, nela também tomam corpo expressões de intolerância, segmentações e exclusões que se traduzem em esforços de estabelecer limites, identidades e espaços protegidos e exclusivos, onde reincidem as hierarquias relacionadas a gênero e classe.

Do ponto de vista das relações de cor/raça, a configuração espacial da ocupação histórica na cidade de São Paulo resultou numa clivagem demarcada pela oposição entre as categorias "centro" e "periferia", imaginadas respectivamente como territórios mais ou menos "brancos". O elemento "pardo" ou mestiço pode ser associado a uma população migrante nordestina, embora muitos desses se vejam como "brancos" e mesmo como "negros". Assentados majoritariamente na chamada periferia, o referente geográfico "nordestino" se modula ao racial de formas diversas não se configurando de modo unívoco. Ainda assim, à imagem de uma clivagem territorial e "racial" corresponderia uma clivagem socioeconômica, resultando na representação da periferia paulistana como lugar da população pobre, trabalhadora, migrante, negra e mestiça (menos branca, neste sentido), em meio à qual vicejaria um sentimento forte de marginalização em contraposição à população dos bairros identificados como "centro", mais bem servidos de equipamentos e serviços urbanos em geral, assim como de espaços de cultura, lazer e diversão. Nesse sentido, "periferia" e "centro" são categorias que remetem a um imaginário que fala de mundos singulares e contrapostos, separados pelas desigualdades sociais. ${ }^{12}$

${ }^{12}$ Para uma reflexão sobre a "periferia" como categoria relacional, ver Frúgoli (2005). 
Jeitos de corpo

A encarnação da periferia paulistana em uma população marginalizada, premida entre o trabalho precário e a ilegalidade, predominantemente "negra", encontrou na chamada "cultura hiphop" da virada do milênio uma de suas principais expressões estéticas e ideológicas. ${ }^{13}$ Uma negritude afirmativa, associada à virilidade agressiva, à malandragem e ao crime, corporificou-se na figura do "mano". De termo informal para "irmão" $e$, por extensão, para "amigo", "camarada", "colega" ou "parceiro", "mano" tornou-se uma categoria para designar rapazes de periferia, negros e mestiços, especialmente aqueles que gostam de rap e hip-hop e adotam estilos de corpo e indumentária associados a esses ritmos de música, dança e poesia. "Mano" às vezes tem conotações pejorativas (como marginal, violento, tosco, brega), mas é também uma forma de tratamento comum entre rapazes de periferia e aparece não só em letras de grupos de rap paulistanos (como os famosos Racionais MC, cujo líder, aliás, é conhecido como Mano Brown), mas já também em outros produtos da indústria cultural (por exemplo, o programa "Manos e Minas", da TV Cultura).

Essa oposição "centro"/"periferia" sintetiza a perspectiva dos estudos de sociologia, antropologia e urbanismo nos anos 1970 e 1980 voltados a caracterizar o processo segmentado e excludente de desenvolvimento urbano de São Paulo, dentro do processo mais geral de modernização implementado pelos governos da ditadura militar. ${ }^{14}$ É importante notar, porém, que "centro" não corresponde exatamente ao "centro histórico", já que essa área da cidade sofreu, durante esse mesmo período, um significativo esvaziamento de suas funções de coração financeiro, comercial e cultural. Transeuntes e moradores de classes populares têm presença marcante e crescente no "centro histórico" de São Paulo

\footnotetext{
${ }^{13}$ Para uma etnografia do campo de representações estéticas sobre a periferia paulistana, além do hip-hop, ver Nascimento (2009).

${ }^{14}$ Para um conjunto expressivo e influente desses estudos, ver Kowarick (1988).
} 
desde pelo menos meados da década de $1960^{15}$; o que, em certa medida, permite falar da região também como um reduto de formas e espaços de lazer que atraem jovens negros e mestiços: rodas de samba, bailes black e suas variações, que reelaboram imagens e representações de identidade negra por meio de música e dança, notadamente da black music afro-americana, e estilos de apresentação corporal vinculados a uma espécie de "negritude globalizada". ${ }^{16}$

Do ponto de vista das territorialidades homossexuais, negras e mestiças, o centro histórico de São Paulo apresenta-se, pois, como um campo que propicia interpenetrações entre "periferia" $e$ "centro", permitindo encontros e interações que reelaboram articulações entre gênero e sexualidade, bem como cruzam

${ }^{15}$ Como nota Frúgoli (2000:61), "o processo de crescente popularização do Centro, a partir de meados dos anos 60 , foi concomitante ao início da evasão de empresas e bancos para outros subcentros, à deteriorização de partes de seus equipamentos urbanos e ao declínio de seu valor imobiliário".

${ }^{16}$ Conforme Roy Shuker (1999), em seu Vocabulário de música pop, o conceito de black music é muitas vezes comparado com o de música afro-americana, ou os dois termos são usados indistintamente. A existência da black music baseia-se na ideia de coerência musical de certos gêneros considerados negros (particularmente o blues, o soul ou rythm and blues, o rap) e do público que com eles se identifica, evocando argumentos sobre autenticidade, marginalização $e$ inclusão dos artistas negros. O conceito de "diáspora negra" foi aplicado à black music para indicar uma "comunidade imaginada" (Anderson, 2008) de povos dispersos, de origem na África negra, cuja expressão musical transcenderia os nacionalismos (cf. as noções de "Atlântico negro" [Gilroy, 2001, 2007]; ou de "globalização negra" [Sansone, 2004]). Dessa perspectiva, Macedo (2007) sugere que rodas de samba e bailes black na cidade de São Paulo são espaços privilegiados de construção identitária de uma população jovem negra que remeteriam à "globalização negra" a qual se caracterizaria especialmente pela divulgação, em escala mundial de musicalidade, estilo de vida e estética vinculados às população negras do eixo Nova York, Los Angeles, Kingston e Londres. $\mathrm{O}$ boom de ritmos como o rap, o $R \& B$, o raggamufin, aliados à crescente influência da mídia televisionada e escrita, teriam promovido uma estética negra renovada do ponto de vista plástico, ligada ao consumo, e que reelabora convenções sobre a identidade das populações de origem na diáspora negra. 
Jeitos de corpo

barreiras de cor/raça e classe. Lugares de lazer e sociablidade erótica podem ser terrenos férteis para avaliar como pessoas materializam visões de si mesmas com vistas a se aproximar e se distinguir: não estamos falando apenas de pura diversão ou escape, mas também de expressão e projeção de aspirações e desejos. Assim, no esforço de mapear e desvendar as articulações entre esses marcadores de diferença, daremos ênfase à dimensão estética. A estética pode ser construída de diferentes maneiras, de modo a destacar ou encobrir os distintos atributos de prestígio ligados à produção social de cor/raça ${ }^{17}$, assim como de gênero $e$ sexualidade.

Sugerimos aproximar essas preocupações à noção de estilo formulada por Hebdige (1979; 1988), como arranjos voltados à produção e performance de corporalidades que lidam com valores $e$ representações associados a marcadores de diferença, reelaborando contextualmente seu significado e seu impacto nas interações sociais. ${ }^{18} \mathrm{O}$ estilo é um jeito de "dar-se a ver" em público, uma forma de encenação e comunicação (Abramo, 1994). Essa concepção abre espaço para considerar formas de produção de subjetividades e identidades por meio de um esforço (sempre parcial $e$ inacabado) de articular anseios, interesses e expectativas de auto-imagem pessoal e coletiva a determinados objetos, corpos e práticas significativas.

${ }^{17}$ Conferir, a propósito, o uso da expressão "relações heterocrômicas" (em vez de "inter-raciais"), que Moutinho (2004) faz com base no trabalho clássico de Thales de Azevedo (1975), chamando a atenção exatamente para a dimensão estética da construção social da "cor".

${ }^{18}$ A visão de Hebdige salienta a capacidade dos grupos subalternos de "embelezar, decorar, parodiar e, sempre que possível, superar uma posição subordinada que nunca foi de sua escolha". Abramo (1994) usou muito proveitosamente essa perspectiva em sua pesquisa sobre as cenas punks e darks em São Paulo nos anos 1980. Facchini (2008) também dela se valeu em sua pesquisa sobre vivências de mulheres homossexuais em São Paulo. 


\section{Uma volta pela Vieira: operando classificações e hierarquias}

A área compreendida pela Praça da República, a Avenida Vieira de Carvalho e o Largo do Arouche, no centro histórico de São Paulo, tem abrigado territorialidades associadas à frequência homossexual $^{19}$ há várias décadas. ${ }^{20} \mathrm{~A}$ Vieira, como é mais conhecida, é um rua com três quadras em forma de boulevard que liga a praça da República ao largo do Arouche. Fica próxima a uma estação de metrô $e$ a estações de trem $e$ a corredores viários percorridos por dezenas de linhas de ônibus, o que faz dela uma área de acesso facilitado e barato, tanto para moradores da região como para moradores de bairros e municípios distantes de diferentes zonas da região metropolitana. O entorno oferece espaços e serviços que permitem convivência ou mesmo lazer durante o dia e no final do expediente comercial.

A Vieira concentra uma variedade de estabelecimentos comerciais destinados ao lazer noturno que ocupam também as transversais, o Largo do Arouche e outras ruas do entorno. Essa

\footnotetext{
${ }^{19}$ Neste trabalho, utilizamos as categorias homossexual e bissexual, dada sua recorrência na bibliografia relacionada à sexualidade, mas é necessário enfatizar que essas categorias indicam de forma genérica toda uma população que não necessariamente se reconhece nelas, apesar de estabelecer relacionamentos afetivos e sexuais com pessoas do mesmo sexo ou de ambos os sexos. Na Vieira, encontra-se ampla gama de pessoas que se qualificariam como "entendidos", "homem que gosta de homem", "gay", entre outros. Além disso, tais categorias se cruzam com outros pertencimentos que vão além da definição a partir da orientação sexual: é o caso dos "ursos" (homens de aparência viril, que cultivam barbas e bigodes e rejeitam uma aparência corporal composta por músculos tidos como excessivamente trabalhados), dos "coroas" (homens mais velhos), entre outros. Para fins de descrição geral e de inteligibilidade, no entanto, abordaremos tais diferenciações apenas nos momentos em que se mostrarem relevantes para a análise.

${ }^{20}$ Para uma visão dos pontos de encontro de homens homossexuais em São Paulo antes dos anos 1960, ver Barbosa da Silva (2005). Sobre a expansão dos lugares de consumo e sociabilidade homossexual em São Paulo nos anos 1970 e 1980, ver MacRae (2005), Perlongher (2008), Simões e Facchini (2009). Para as décadas mais recentes, Simões e França (2005), França (2010).
} 
Jeitos de corpo

região do centro abrange áreas de prostituição de rapazes, garotas e travestis, pontos de comércio de drogas ilícitas, boates de prostituição de garotas, casas de strip-tease e sexo explícito, danceterias direcionadas ao público homossexual, saunas gays, cinemas "de pegação", sex shoppings, lan houses, bares, ruas e praças públicas onde ocorrem paquera e "caçação".

Os estabelecimentos comerciais de lazer noturno da Vieira reúnem um público que se distribui de maneira relativamente segmentada. Numa das calçadas da primeira quadra da rua concentram-se alguns bares de frequência marcada de homens mais velhos ao redor dos quais orbitam rapazes mais jovens. No segundo quarteirão, e se espalhando até o fim da rua, há uma sequência de estabelecimentos, atraindo frequentadores que se concentram às suas portas e calçada, bem como no seu interior. Nesse trecho, pode-se observar a presença de vendedores informais de bebidas, lanches, bijuterias e CDs de música. Os frequentadores são rapazes jovens, muitos deles negros $e$ mestiços, dentre os quais vários demonstram uma apresentação corporal tida como mais "feminina", com camisetas e calças justas num corte que visa "valorizar as formas do corpo". Nessa quadra também circulam mais travestis e drag-queens. ${ }^{21}$ Também se observa a presença de "michês" ou garotos de programa nas calçadas e na ilha que separa as duas pistas da avenida, assim como de outros rapazes de aparência viril, às vezes malvestidos $e$ de atitude agressiva, chamados de "ocós" 22 pelos demais

${ }^{21} \mathrm{O}$ termo êmico refere-se a homens que se travestem com roupas e acessórios femininos com o propósito de compor um visual e performance cujo tom é dado em grande parte pelo efeito cômico que produzem. As drags são responsáveis pela apresentação de números humorísticos, que poderiam ser caracterizados como humor camp.

22 "Ocó" faz parte de uma linguagem chamada "bajubá" ou "pajubá", que incorpora termos de línguas africanas usados das religiões afro-brasileiras e é praticada, sobretudo, pelas travestis, embora esteja parcialmente disseminada como gíria nas territorialidades homossexuais do centro histórico de São Paulo, assim como de outras cidades brasileiras. 
frequentadores gays. A fronteira entre os michês e esses outros rapazes é altamente porosa. De todo modo, a eles são atribuídos atos de violência que eventualmente ocorrem no local, como furtos e roubos acompanhados de agressão física. Nessa quadra da Vieira, assim como em outras ruas da região, também operam franjas do comércio de drogas ilícitas, no qual se envolvem alguns garotos de programa e travestis.

$\mathrm{Na}$ quadra final da Vieira, já adentrando o Largo do Arouche, há uma fileira de bares chamada de "Prainha do Arouche", todos com a mesma característica: abertos, com muitas mesas na calçada, frequentados por casais e grupos de amigos, homens e mulheres, principalmente nas noites de sexta-feira $e$ sábado e nas tardes de domingo. Outros estabelecimentos (bares, botequins, boates, saunas, clubes de sexo) espalhados pelo Largo do Arouche e pelas transversais da Vieira, assim como em ruas próximas, atraem um público de homens homossexuais de várias idades.

A diversidade de pessoas e a razoável convivência são características recorrentemente apontadas pelos frequentadores da Vieira. Apesar das menções a alguns episódios de violência, é comum ouvir dos frequentadores uma visão positiva e harmônica da diversidade presente: a Vieira é "legal", porque "é democrática", "tem de tudo", "não tem preconceito". Como disse um jovem frequentador que se identificou como gay e negro: "É um lugar aberto, você anda de mão dada, você beija na rua, não tem pra se preocupar não, aqui você tá liberal, é um lugar que você se sente até feliz".

Os frequentadores afirmam que na Vieira também se sente menos pressão e constrangimento para se adequar aos padrões $e$ estilos de corpo e de vestimenta mais valorizados na cena gay de maior visibilidade: lá não se encontram exclusivamente "os homens musculosos, esculturais", nem apenas os "garotos descolados com a calça mostrando a cueca, ou com a camisinha apertada, magros e definidos". 
Jeitos de corpo

A diversidade presente abre espaço para parcerias entre diferentes, seja em termos de idade, cor/raça ou performance de gênero. É recorrente, por conta disso, a representação da Vieira como um lugar onde se pode encontrar a companhia de homens para sexo homossexual casual com grande facilidade. A visibilidade dos rapazes "da periferia" dentre os frequentadores da Vieira e a percepção que combina a predominância de classes populares com a alta oferta de possibilidades de encontros sexuais parecem se alimentar mutuamente. $\mathrm{Na}$ cena dos bares e boates gays paulistanos da moda paira um estigma em relação à região da Vieira e sua população, que as associa a um desvalorizado juízo moral, comportamental e estilístico. Nesse imaginário, a área estaria relacionada a noções de promiscuidade e prostituição e a estilos "bregas" $e$ "populares". Isso se expressa nas referências à Vieira como ponto de concentração das "bichas-pão-com-ovo", termo depreciativo usado entre os próprios homossexuais para designar rapazes mais pobres que moram nos bairros mais distantes e dependem de transporte público; assim como das "bichas quá-quá", rapazes de comportamento mais afeminado e espalhafatoso.

$\mathrm{O}$ fato de muitos jovens frequentadores da Vieira virem de bairros longínquos, com atributos depreciativos daí decorrentes, é também largamente satirizado nos shows comandados por drag queens nas casas noturnas da região. Nesses espetáculos, as drags apresentadoras escolhem pessoas da clientela para realizar algum tipo de performance, pela qual recebem prêmios singelos. Ao convidar um rapaz (ou, mais raramente, uma garota) para subir ao palco, invariavelmente a drag pergunta onde a pessoa mora, $e$ exagera a distância do local indicado e o fato de se situar na periferia: se a pessoa diz que mora em um bairro afastado, a drag pode retrucar: "não mora, mas vive em cativeiro". Referências sarcásticas às roupas e à aparência dos entrevistados, sempre para enfatizar sua condição de classe baixa, são também ingredientes habituais desses espetáculos, nos quais as próprias drags se autoironizam, já que muitas vezes encarnam os mesmos marcadores 
de seus convidados. O lado mais ferino, mordaz e maledicente da cena gay se evidencia aí com todas as suas fortes tintas. Como contou um rapaz que se identificou como gay e negro:

Sabe a Silvetty Montilla? [refere-se a uma famosa drag animadora de shows em casas noturnas gays de São Paulo] É ídolo gay, né? Todo mundo conhece. Ela é negra, e vive gongando ${ }^{23}$ o cabelo dos outros! Vive gongando! Ela é negra: usa peruca. Peruca lisa, sempre, né. De várias cores! Daí ela grita: tenho cabelo liiindooo!

As marcas de gênero são as que mais se evidenciam na corporificação desses estigmas de pobreza, ausência de refinamento cultural e certa propensão à promiscuidade sexual. Mesmo na Vieira, nos quarteirões em que rapazes se divertem em "dar pinta", os tipos que parecem mais masculinos, mais discretos e menos espalhafatosos tendem a ser os mais desejados. Assim, é possível observar uma contenção dos rapazes de performance mais feminina quando se engajam efetivamente na paquera e no esforço de atrair alguém que lhes tenha despertado interesse ou lhes dirija a atenção.

Marcadores de cor/raça combinam-se a outros marcadores, incidindo fortemente nos relacionamentos e nas possibilidades de parceria, ainda que de forma mais sutil e menos explícita. Assim, a combinação entre certo estilo de vestimenta (boné, camiseta regata justa, bermudão ou jeans), tipo físico (alto e musculoso), performance de gênero (masculina) e cor de pele escura produzem a figura do "negão". Os rapazes que se encaixam nessa figura tendem a ser alvo de grande interesse erótico e podem ser tomados por garotos de programa. Manifestam-se também, em relação aos rapazes negros, expectativas convencionais

23 "Gongar" é um termo êmico que significa ridicularizar ou caçoar de alguém. Possivelmente sua origem remete ao gongo que soava nos antigos programas de calouros na TV para reprovar candidatos. 
Jeitos de corpo

relacionadas a tamanho de pênis, potência e desempenho sexual acima da média.

Acrescenta-se ainda a convenção de que os negros são mais sensuais por causa de sua maior habilidade para a expressão corporal, notadamente para a dança. Nesse caso, porém, a negritude pode levar a uma performance de gênero e uma expectativa de papel sexual exatamente oposta à do negão, a qual pode ser referida por meio de categorias como "bicha-preta" ou "bicha-close". Pedro, um jovem frequentador gay e negro da Vieira, elaborou contrastes entre brancos e negros segundo polarizações corpo versus racionalidade, que usou como justificativa de sua própria identificação:

Quando você pensa num negro, você pensa em pessoas mais relaxadas, menos pragmáticas, muito mais emocionais, passionais, muito mais intensas. Os negros são muito mais corpo do que racionalidade... Enquanto que os brancos, pelo menos é o que a gente aprende, os brancos são muito mais pragmáticos, sistemáticos, pensam mais antes de fazer. Os negros são intensos em tudo, é por isso que eles gostam de música, de dança... Por isso que eu digo: eu me considero negro, porque eu tenho todas as características que eu aprendi que negro tem! Eu sou uma pessoa muito pouco pragmática, muito emocional, muito físico, dança pra mim é a melhor coisa, música, então! Sou uma bicha hiper close, eu adoro dançar, adoro dublar, adoro fazer caras e bocas, entendeu? Eu gosto de movimento, swing! Tudo que todo negro normal, ou comum, ou comumente é! Então, eu me considero negro por isso, não pela minha aparência. ${ }^{24}$

${ }^{24}$ Difícil não evocar aqui, a partir da fala de Pedro, a visão do "ser negro" não como fenótipo ou cor física, mas como uma "disposição" de ordem psíquica e cultural, visão marcante na literatura $e$ nos ensaios brasileiros sobre raça $e$ relações raciais após os anos 1930. Como comentou Martínez-Echazábal (1996:18), trata-se de uma "cor espiritual", na medida em que o ser negro ou mulato afirma-se "mediante diversas formas social e culturalmente determinadas de apreender o mundo". 
Pedro é filho de pai "negro" com mãe "branca nordestina" e morou em bairros populares próximos da região central da cidade; seus amigos de infância e adolescência eram "brancos, de classe média e média baixa". Vale considerar um pouco mais sua fala, pois ele é um dos raros entrevistados que tornou explícitos sentimentos de discriminação por causa de cor/raça, que, no seu caso, parecem mais dramáticos em vista de sua própria preferência estética e erótica por certo tipo de rapazes brancos (que ele definia como tipo "siciliano": "pele branca rósea, olhos claros, cabelos lisos e pretos") e consequente rejeição por parceiros que classificava como "negros", como a si mesmo. Sua narrativa, evocando toda sorte de estereótipos que desqualificam esteticamente os pretos ("têm pele grossa", "cheiram mais", "são suados", "têm testão", "têm cabelo ruim"), descortina uma hierarquia estética no universo gay que envolve atributos de cor/raça e de apresentação pessoal, como signos de classe $e$ prestígio, que usualmente se mantém velada e não se pronuncia com tal eloquência:

Existe um padrão gay que todos os gays amam: é cabelo liso, branquinho, traços finos, europeus. Todos os gays valorizam isso. Então, se você não tem isso, vem a famosa gongação. Uma bicha gongada é uma bicha que não se encaixa nos padrões que os gays acham legal, que não se veste com roupa na moda ou de marca, entendeu? Que não tem o cabelo hiperproduzido, alisado... Gay adora gongar o outro, adora criticar! Então, gay negro sofre muito! Ai, que cabelo ruim! Ai, esse nariz! Nossa, já peguei tanta situação com outras pessoas. Mais pelo cabelo, né?! Porque meu cabelo está cuidadinho agora, mas antes meu cabelo estava num aspecto mais natural mesmo, sabe? Então, nossa, me gongavam muito! $\mathrm{Ai}$, que cabelo, esponjaço, assolan!

Segundo esse ponto de vista, no mercado afetivo-sexual homoerótico, regido por tal hierarquia estética, a posição dos 
Jeitos de corpo

negros que não se encaixam na figura do "negão" seria a mais desvantajosa possível. Essa hierarquia poderia ser interpretada como uma inequívoca desvantagem para os que são identificados como negros. Entretanto, pode abrir campos de possibilidade variados. Vamos considerar agora o caso dos jovens gays frequentadores de um "clube de samba GLS", também conhecido como Boteco do Caê, numa rua próxima à Vieira, que funciona nas noites de domingo. ${ }^{25}$

O clube de samba GLS é frequentado majoritariamente por rapazes de pele escura, de diferentes tonalidades. Apesar de ser qualificado como um "lugar de preto" por alguns frequentadores, é importante enfatizar as porosidades desse espaço em relação a cor/raça: há também muitos brancos que o frequentam - o próprio Caê, o organizador e dirigente do clube, é um jovem gay branco de classe média, fascinado por samba. As gradações de cor de pele percebidas e atribuídas são muitas, havendo uma pluralidade de categorias para referir à cor/raça: "escuro" e "preto" são termos utilizados de modo genérico, mas raramente para referir-se a si mesmo ou para qualificar outros. Em entrevistas e situações de conversa informal, o termo "negro" aparece com mais frequência quando os sujeitos definem a si mesmos em termos de cor/raça.

Isso está associado também à existência de uma estética $e$ apresentação corporal que remete a uma ideia de "negritude" estilizada, na qual os cabelos, em diferentes arranjos, parecem ser um dos traços mais distintivos. Essa estética combina-se, ainda, na composição de um espaço relacionado à "negritude", ao tipo de música e da relação que as pessoas estabelecem entre música, dança e cor/raça, evidenciadas na fala de Pedro. No samba, a dança assume papel fundamental para definir os "de dentro" e os "de fora". Observa-se um investimento muito grande na performance corporal e a dança também media situações de flerte

${ }^{25}$ Para uma discussão ampliada do clube de samba GLS, ver França (2009; 2010). 
- "dançar gostoso" é um aspecto que torna alguém muito mais desejável no samba.

Características que denotam masculinidade e feminilidade são importantes na orientação da paquera e das parcerias. Os rapazes mais femininos circulam mais pelo salão numa passada mais leve, pernas mais fechadas e braços que gesticulam com maior frequência. Suas roupas são mais justas, as camisetas podem ser brilhantes e transparentes, as calças trazem uma profusão de detalhes, como zíperes e bolsos extras. Os mais masculinos circulam e sambam menos, têm gestos mais contidos, sentam-se de pernas abertas; usam roupas largas e de cores sóbrias, colares e bonés de abas curvadas, que cobrem parte do rosto. A dança pode ser também um momento "revelador" dessas características de gênero. Embora certas performances mostrem uma ampliação do repertório de movimentos corporais socialmente aceitáveis a um dançarino de samba (como certo tipo de rebolado praticado por rapazes artistas de "pagode baiano", que replica o movimento da pelve masculina no ato de penetração sexual), há desempenhos que são tidos como reveladores de "feminilidade" - dançar movendo excessivamente os quadris, erguer demais os braços acima dos ombros, ou acompanhar o conteúdo das letras com gestos de mãos que expressem alguns versos.

No clube de samba GLS também aparece o contraste entre a "bicha preta" e o "negão", ou seu equivalente "mano". Apresentamos a seguir as trajetórias de dois rapazes que falam dessas posições de sujeito sempre em complexa negociação.

Tuca se identifica como gay e negro, mas também se considera uma "bicha preta", pois é cabeleireiro, estilista e maquiador. Filho e neto de empregada doméstica, foi criado pela avó em uma casa de família de classe média na capital paulista. Quando a avó perdeu o emprego, mudou-se para um município na periferia leste da Grande São Paulo. Conseguiu inserção na área de moda, cabelo e maquiagem ao fazer contato com lojistas da Rua São Caetano, um lugar especializado em produtos $e$ 
Jeitos de corpo

serviços para noivas na capital paulista, para onde foi com o objetivo de vender uma peruca que pertencia à avó. Foi também quando conheceu seu namorado - branco, filho de uma família judia de classe média, dez anos mais velho - que o incentivou a retomar os estudos e se especializar em moda e cabelo. Tuca acredita que gostar de relacionar-se com rapazes marcou um diferencial positivo em sua trajetória. Quando imagina sua vida sem a homossexualidade, diz que poderia

ser pai de 30 filhos, com um salário mínimo por mês, morar com os pais, ou alugar uma casinha bem humilde, morar num lugar humilde. Claro que ser gay não quer dizer morar em lugar luxuoso, ter grana, mas acho que gay tem tanta sacada pra trabalho, pra dinheiro, pra profissão, pro mundo em geral...

Experiências sexuais com outros garotos eram corriqueiras para Tuca desde a infância. Como vários outros jovens entrevistados, ele conta que a vaga percepção que tinha de si mesmo, de "ser diferente", ganhou outro significado quando na adolescência passou a ser chamado de "bicha". Uma de suas estratégias foi buscar conquistar a simpatia das pessoas usando a irreverência e a animação que seriam próprias da "bicha". Tuca costuma assumir gestos e posturas femininas que define como "bichar", mas não considera isso necessariamente uma desvantagem. Ao contrário, acredita que é o que o faz notado.

Se eu não bichar eu passo batido e se eu bichar eu aconteço. Aonde eu vou, se eu der uma bichadinha, pronto, acontece! A mulherada vem, quer dançar... Uma fervidinha, jogar o cabelo, cruzar as pernas, fazer um gesto, não precisa grande coisa. O fato de ser gay e usar essa coisa faz com que as pessoas se aproximem mais de mim. 
A trajetória de Tuca é marcada por situações de contraste e por relacionamentos que lhe possibilitaram atravessar barreiras de classe. Essa experiência talvez o coloque numa posição especial, de viver o impacto de estar sempre deslocando expectativas $e$ convenções relacionadas a sua posição social, cor/raça, gênero e sexualidade, como revela ao falar da época em que tinha um automóvel:

Não que me olhassem diferente, com carro ou sem carro, mas você vê um Ford Ka passando, de repente desce uma bicha preta, de canecalon comprido, batendo na bunda. O povo fica meio assim: "uau, que estilosa". Tanto que um amigo falou pra mim: "meu, adoro ver você chegando com o seu carro, quando você sai do seu carro, você joga o cabelão!".

Enquanto o carro, um indicador de status, e o cabelo canecalon comprido fazem a "bicha preta" ser observada na rua como "estilosa", outros penteados ou estilizações podem remeter a estereótipos negativos, como também revela Tuca:

Com aquelas trancinhas rastas não fico bem, fico com cara de marginal. Com touca eu fico com cara de marginal. Se eu puser uma touca, você, que me conhece, na hora levanta a mão e chama o segurança: "pode levar!" [risos]. Fico o próprio marginal!

Para Tuca, parece haver possibilidades variadas, na interação com outras pessoas, para reverter em seu favor um conjunto de atributos (preto, homossexual e afeminado) socialmente desvantajosos. Vejamos, como contraste, o caso de Rodrigo, um rapaz que se identifica como homossexual e negro, também filho de empregada doméstica que, na maior parte de sua vida, morou em bairros populares da Grande São Paulo.

Rodrigo conta que desde a infância tinha atração por outros rapazes. Na adolescência, sentia que "ser homossexual" o 
Jeitos de corpo

afastava da convivência com a maior parte de seus pares no bairro, com exceção de um amigo, com quem pôde compartilhar ansiedades e dúvidas sobre o que até então era por ele "vivido na fantasia". Ambos conheceram lugares no centro de São Paulo onde viram rapazes que trocavam carícias e se beijavam. $\mathrm{O}$ amigo logo passou a frequentar esses lugares, se "deslumbrando" com aquilo, passando a fazer brincadeiras como "rebolar na rua" $e$ "perdendo o jeito de "moleque"". Rodrigo não aprovou as mudanças e acabou se afastando também do grande amigo $e$ confidente. Começou então o que Rodrigo chamou, não sem ironia, de "fase negra" de sua vida, em que conta ter vivido uma grande solidão.

Desde cedo, a única consciência que tinha era de que eu não deveria ser um cara efeminado, e daí você sabe o que não deveria ser e procura pessoas como deveriam ser $e$ começa a tentar encontrar agulha num palheiro. Daí fui procurar outra turma. E minha turma era a turma com quem eu não falava da minha sexualidade, mas tinha a ver comigo... Era complicado... Porque essa sexualidade faz você se tornar um grande mentiroso... E isso me deixava frustrado porque no fundo eu não queria que fosse assim. Então eu queria um mundo que não existia.

A combinação entre morar na periferia de São Paulo, ser negro, se identificar com a postura e a estética relacionadas ao hip-hop, ser alto, forte e adotar uma performance de gênero masculina fazia com que Rodrigo fosse identificado como "mano". Isso o tornava um chamariz sexual no contexto do mercado homoerótico. O que pareceria ser vantajoso, porém, era por ele vivido como extremamente frustrante. Ser "mano", para Rodrigo, o colocava numa situação desigual, pois sentia que se objetificava ao olhar do outro. Sua principal queixa era a de que as pessoas aproximavam-se dele exclusivamente com intenções sexuais: 
Eu não me considerava mano. Era meu jeito de falar, meu jeito de ser, mas eu não me considerava mano, não. Eu nunca achei que a malandragem, o fato de eu ser da periferia, fosse uma coisa legal, fosse o máximo. Pra mim, não. Eu morava lá, mas eu queria uma vida melhor pra mim também. Eu não queria me mostrar um pseudomarginal, pra bancar a onda desses caras que gostam de marginalzinho, assim, sabe? Tem muito cara que gosta de fazer o estilo: "vou pegar um cara com jeitinho de mano". Apesar de eu saber que a imagem que eu passava era justamente essa. E eu brincava com isso, eu gostava de brincar com isso, porque na verdade por dentro eu dava risada.

Ao comparar as histórias de Tuca e Rodrigo, vemos que, com todas as dificuldades que o lugar de "bicha preta" podem ter trazido a Tuca, ainda assim é um lugar confortável, possibilitando interações que podem não ser as sonhadas, mas são as possíveis $e$ vistas como positivas. Já Rodrigo fala de um quase não-lugar, de não ser "bicha", de recusar a estratégia que seus amigos adotaram na adolescência para se relacionarem com pessoas do mesmo sexo e de, ao mesmo tempo, não encontrar vantagens em ser tido como objeto de desejo por ser "mano", "negro", "macho" e "da periferia". Embora Rodrigo use roupas e acessórios (bermudas ou calças jeans largas, tênis de skate, bonés) que realçam propositalmente sua corporalidade de "mano", seja para impressionar potenciais parceiros ou se afastar de situações que o incomodam, sua narrativa expressa desconforto com as convenções de masculinidade, classe e raça que se sente obrigado a operar e com as relações que eventualmente constrói a partir delas.

Outros cruzamentos entre marcadores de cor/raça e gênero podem ser observados na Gruta, uma boate nas adjacências da região da Vieira que atrai principalmente mulheres homossexuais de classe baixa, a maioria negras e mestiças que vivem em bairros populares das periferias de São Paulo. Essa boate mescla em sua 
Jeitos de corpo

programação shows de samba, com um grupo composto exclusivamente por mulheres, som mecânico, axé, funk carioca e estilos de black music.

Entre o público da Gruta prevalece a diferença entre mulheres com performance de gênero mais masculina e as que se apresentam de maneira mais feminina. As masculinidades variam segundo um recorte geracional. As mulheres "masculinas", acima dos 30 anos, trajam camisa e calça social ou jeans de corte masculino, sapatos baixos, trazem os cabelos curtos e usam cores sóbrias. Seu modo de andar é mais duro e seus gestos contidos; dançam pouco ou mal se movimentam ao dançar. A maior parte do tempo ficam jogando bilhar; ou, quando em atitude de paquera, observam o movimento junto à mesa de bilhar ou nos cantos da casa, sempre com uma bebida na mão. As "masculinas" mais jovens, em contraste, assumem uma aparência que evoca o estilo dos "manos": calças jeans largas, tênis de skatista ou de jogador de basquete, camisetas coloridas largas, algumas com correntes unindo os bolsos da frente e traseiros da calça, piercings no queixo e nas sobrancelhas e tatuagens. Muitas usam bonés, outras compõem topetes ou fios arrepiados. Para essas garotas, a dança é um momento privilegiado de paquera: seu gestual é mais solto e elas movem-se com desenvoltura pela pista, reproduzindo a ginga $e$ o gestual dos rapazes associados ao hip-hop.

Entre as mulheres femininas na casa, há menos variações de vestuário, gestual e comportamento. As roupas são sempre justas, com blusas coladas ao corpo e decotadas, muitas vezes deixando a barriga à mostra. Nos pés, sandálias ou sapatos e botas de salto. Usam brincos e colares vistosos, cabelos longos, muitos tingidos de loiro ou alisados. Na dança, fazem movimentos que lembram dançarinas de axé ou funk carioca, passistas de escolas de samba $e$ estrelas sensuais da black music norte-americana.

As parcerias na Gruta são orientadas quase exclusivamente segundo a lógica "masculina/feminina", com raras variações que admitem o par "feminina/feminina", mas nunca o par "masculina/masculina". Estilizações de aparência, gestos $e$ 
vestimentas que não sejam marcadamente masculinas ou femininas não são valorizadas e não parecem despertar atração ou interesse erótico. Performances que lidam de forma mais lúdica com as convenções de gênero acontecem com certa frequência, mas nem sempre são bem-sucedidas. Certa ocasião, uma garota "masculina" entrou no palco vestida de cow-boy, fez um inusitado show de strip-tease e, com gestos contidos, foi despindo peça por peça até ficar apenas de coturno e cueca tipo boxer. Quando tirou a última peça, as demais mulheres "masculinas" presentes, atônitas com os rumos do espetáculo, protestaram que aquilo tinha passado dos limites e "depunha contra a imagem de todas as masculinas ali" (Facchini, 2008:99). O show terminou num silêncio constrangedor.

\section{No baile black: distanciamentos e aproximações}

O Sambarylove é uma casa noturna situada no bairro da Bela Vista, área popularmente conhecida como Bixiga, muito próxima ao centro histórico de São Paulo. O curioso nome do clube é uma transcrição fonética da expressão inglesa somebody loves, a partir da famosa interpretação de Frank Sinatra para a canção All the way, sucesso do final dos anos 1950 (com seus versos iniciais: when somebody loves you / it's no good unless he loves you / all the way). ${ }^{26}$ De acordo com o proprietário, a designação seria "a junção de samba e amor".

Quando a casa foi inaugurada, no começo dos anos 1990, a região onde está localizada era uma mancha de lazer bem mais concorrida do que atualmente. Atualmente, o clube recebe um público de rapazes e moças na faixa dos 20 anos, a maioria negros e mestiços, de classes populares e moradores de bairros periféricos da cidade. A grande oferta de transporte para a região central e o baixo preço da entrada são fatores que contribuem para a

${ }^{26}$ Numa tradução livre: "quando alguém ama você, isso não é bom, a menos que ele ame você de todas as maneiras". All the way, composta por James Van Heusen e Sammy Cahn, ganhou o Oscar de melhor canção em 1957. 
Jeitos de corpo

popularidade da casa, que funciona nas noites de sexta-feira $e$ sábado, das 23 às 5 horas da manhã, combinando shows de pagode e som mecânico com black music, e ainda promove uma matinê aos domingos, das 19 horas à meia-noite, atraindo um público ainda mais jovem ao som de black music tocada por DJs. Para esses jovens, o transporte público é essencial: alguns chegam a utilizar duas ou até três conduções para chegar ao local e muitos vão embora antes de a casa fechar, porque não dispõem de outro meio de retornar para casa.

Os ritmos musicais internacionais, com o respectivo prazer da dança - chamados de forma genérica pelos frequentadores de black ou hip-hop -, para além da possibilidade de encontros afetivos, são o grande atrativo do clube para seus jovens frequentadores. Vários desses jovens circulam por outras casas que tocam black music. Alguns rapazes, em particular, cursando faculdade ou já formados, exibiam grande conhecimento a respeito da black music, comentando sua história, os artistas mais conceituados e mais populares, estilos, danças e variações. Dentre esses, alguns também atuavam no movimento negro.

A black music afro-americana internacionalizada, com sua estética e representações de gênero e sexualidade encenadas nos videoclipes de artistas de $\mathrm{R} \& \mathrm{~B}$, soul e hip-hop, fornece elementos importantes para os modos como os frequentadores constroem sua apresentação corporal e suas performances de gênero. As garotas usam vestidos, tops, saias curtas ou jeans sempre muito justos, que realçam as formas do corpo, notadamente seios $e$ quadris. Algumas usam estilos "afros" de cabelo, como os trançados, mas a grande maioria traz os cabelos alisados $e$ frequentemente clareados. Os rapazes vestem variações do estilo "mano" ou hip-hop", com calças e camisetas largas combinadas com acessórios - correntes, anéis, bonés, tênis de vários tipos ou botas. Os cabelos são curtos ou raspados, trançados ou black power.

As performances de gênero são marcadamente diferenciadas e erotizadas para ambos os sexos. Na dança, garotas 
e rapazes evocam os respectivos desempenhos femininos $e$ masculinos da estrelas dos videoclipes de black music: elas agem de forma bastante "feminina", com gestos sinuosos e coreografias sensuais com muitos movimentos de braços e quadris; eles adotam maneirismos viris, com movimentos angulosos de mãos e corpo e uma ginga contida, dançando quase sem sair do lugar. ${ }^{27} \mathrm{E}$ comum a exposição dos frequentadores a vídeos de músicas, cujo cantor, quase sempre negro de tonalidade de pele escura, está acompanhado e interagindo afetiva e sexualmente com outras mulheres.

Se essas observações corroboram a visão usual de que a heterossexualidade é parte constitutiva do imaginário vinculado à black music, não deixa de ser interessante ressaltar a correspondência termo a termo entre a indumentária $e$ as performances vistas entre os rapazes do Sambarylove e as garotas masculinas mais jovens da Gruta, assim como eram similares as caracterizações da feminilidade em ambos os clubes.

No Sambarylove a paquera é constante, e mesmo que a maioria das pessoas afirme que o maior atrativo do clube seja a música, a maior parte do tempo é dedicada a flertes e trocas afetivas. A aproximação das mulheres se inicia com trocas de olhares e exibição através da dança e da vestimenta. Uma amiga pode intermediar o primeiro contato. $\mathrm{O}$ mais comum é que o homem se dirija à mulher, abordando-a diretamente e deixando claro seu interesse por ela através do toque no corpo (na barriga, nos braços, no pescoço) e de argumentos como "você é muito linda", "estou apaixonado por você", "você é especial", etc. Essas falas buscam diferenciar a garota que está sendo abordada de outras meninas com quem ele possa ter "ficado". Os rapazes buscam "ficar" com o maior número de garotas, se possível na mesma noite. Já na fala das mulheres há mais romantismo, e a

${ }^{27}$ Videoclipes de canções interpretadas por estrelas da black music norteamericana como Beyoncé e Akon podem servir de referência para as respectivas performances de gênero femininas e masculinas vistas no clube. 
Jeitos de corpo

maioria delas diz estar à procura de relacionamentos mais sérios. Apesar disso, acontece frequentemente de as meninas "ficarem" com mais de um rapaz durante a noite e usarem a justificativa de que estavam "bêbadas" ou que estavam "solteiras" $e$, portanto, "tinham que curtir a vida". Afinal de contas, como disse uma garota, "os meninos fazem o mesmo". Os rapazes justificam-se: "homens são assim mesmo".

O Sambarylove é um espaço predominantemente black, mas as poucas pessoas brancas presentes parecem bem inseridas no local, em geral acompanhadas de amigas e amigos negros. A minoria dos brancos presentes também compartilha a estética black predominante, o que parece funcionar como um contraponto para o imaginário disseminado no clube, que associa as pessoas de cor de pele mais clara a posições mais altas de classe e status.

As pesquisadoras que mais exploraram esse campo - duas jovens universitárias identificadas como brancas, que não se vestiam no estilo black predominante - relataram experiências diversas em suas interações com os rapazes negros e com as garotas negras. Para os rapazes, de início, as pesquisadoras pareceram "patricinhas". Isso as tornava alvo de paquera, o que facilitava seus primeiros contatos com os meninos, mas não com as meninas. Quando se apresentavam como estudantes da USP, o interesse dos rapazes crescia, especialmente entre aqueles que mencionavam com ênfase que "faziam faculdade", queriam "crescer na vida" e afirmavam que ter alguém como elas ao seu lado seria um "estímulo". Porém, os rapazes se afastavam gentilmente quando percebiam que as estudantes eram pesquisadoras que "só queriam conversar" (ainda que alguns ignorassem a pesquisa e tentassem insistir na paquera). Com as garotas, em contraste, o contato só progredia quando as estudantes se apresentavam como pesquisadoras. A partir daí a conversa fluía com animação $e$ interesse, $e$ as garotas faziam questão de demonstrar às pesquisadoras que elas eram muito bem-vindas ao clube. 
Essas diferentes experiências remetem às diferentes preferências acionadas pelos rapazes e pelas moças do clube na interação afetiva e erótica. Os rapazes negros, em geral, demonstravam preferência por mulheres mais claras, mas o atrativo estético principal está atrelado ao tipo de cabelo, seguido da cor da pele. Um rapaz, por exemplo, afirmou que não se importaria se a mulher fosse "preta" como ele, desde que ela tivesse "cabelo bom", isto é, liso, macio, bem cuidado e apropriadamente "feminino". As mulheres negras e mestiças são, assim, eroticamente desvalorizadas, principalmente pelo cabelo crespo e "ruim". Se a mulher negra ou mestiça tiver cabelos alisados, seu valor erótico aumenta aos olhos dos rapazes e pode até superar o da mulher branca, evocando as potencialidades da "mistura" de traços fenotípicos. Não por acaso, a maioria das garotas vistas no clube tinha os cabelos alisados; e algumas ainda os clareavam.

Como o universo da black music remete a um imaginário de virilidade, expresso nas letras das canções e nos videoclipes, em que o homem negro aparece como portador de uma sensualidade irresistível que atrai e possui mulheres de todos os tipos possíveis, o ideal de masculinidade que prevalece na cena no Sambarylove é o do "negão" charmoso e potente que seduz todas as mulheres (e seria decerto capaz de amá-las "de todas as maneiras", como dizia a canção que inspirou o nome do clube...). Não por acaso, as pesquisadoras foram logo questionadas pelos rapazes por seu suposto interesse erótico por negros. Afinal, como disse um rapaz, "negro virou moda":

Antigamente não tinha muito negócio de baile black, baile black era só pra negro. Agora isso tá muito mesclado, tem funk, o pessoal vai tudo. Se você tá um pouco mais bonitinho, o pessoal te olha com olhos diferentes. As meninas agora ficam, é negro, né. Porque negro virou moda. Virou moda, então pode ficar. Se você vai assim arrumado, sossegado pra conversar com seus amigos e tal, 
Jeitos de corpo

tá de boa, daí as meninas chegam assim em você: "poxa, você tá lindo, parece estilo americano"...

As garotas do clube afirmaram preferir os rapazes negros, altos, de "olhos cor de mel" e trajados ao estilo "mano" ou "hiphop". Quando se expressavam mais espontaneamente, referiamse a esse tipo de rapaz como "negão". Homens mais claros, por sua vez, costumavam ser referidos no diminutivo ("branquinho") $e$ muitas vezes descritos como "mais delicados" que os negros.

O maior interesse por homens negros também se associa a uma avaliação das possibilidades de relacionamento tendo em vista a classe e o status do parceiro. O homem branco é tido como mais "rico", materialista e possivelmente racista. Desse modo, não conviria a quem espera um relacionamento durável. Perguntada se preferia parceiros de sua mesma cor/raça ou de cor/raça diferente, uma garota que se identificava como negra deu a seguinte resposta:

Olha, eu, particularmente, não sou uma pessoa que gostaria de namorar um cara rico, que tivesse carro, dono de empresa. Porque esse cara, ele é pobre de sentimento, ele é feliz profissionalmente. Mas o dinheiro dele não compra felicidade e eu garanto que essas pessoas, hoje, elas são sozinhas. Eu não gosto de namorar com caras brancos, porque no conceito deles, quando ele é branco ele é playboy, ou só pelo fato dele ser branco, as negras são pra comer $e$ as brancas são pra casar. E eu acho que não é bem assim. Hoje tem mulheres brancas e negras, de qualquer cor, que não se dão o mínimo valor e não servem pra nada. Eu prefiro namorar homens, primeiro que tenham um caráter e depois que sejam da minha cor, de preferência, pra não ter uma divergência racial. Então, no meu conceito, eu gosto de namorar pessoas do meu nível social, com a minha cabeça e que tenham primeiramente caráter. Que saibam bem com quem estão lidando. 
A noção de que uma pessoa de classe mais alta é branca e que provavelmente será preconceituosa tem a ver com o modo como os jovens entrevistados relataram experiências com situações em que se viram vítimas de racismo. Nessas situações, a pessoa negra geralmente é tida como alguém que não se veste adequadamente para determinado ambiente, não sabe se portar, é tratada como serviçal ou como possível ladra. Na experiência dos jovens entrevistados, a discriminação se faz, sobretudo, por meio da leitura de signos de apresentação pessoal em relação às marcas corporais, de modo a inferir uma posição social, quase sempre inferior. Como disse um rapaz:

É muito mais pelo visual, assim. Se você tá de chinelo falam que você é maloqueiro, chamam até de mendigo, nome sujo. Se você tá com roupa mais formal, vamos dizer assim, se você tá de social, aí você é segurança... Se você tá num carro importado, ou é ladrão, ou é jogador ou artista. Porque negro, pra ser bem-sucedido, tem que ser jogador, artista, modelo, ou algo do gênero.

Algumas dessas situações de discriminação acontecem no trabalho, mas várias outras, sentidas com especial amargura, se dão em contextos de consumo de bens e serviços. Uma garota descreveu um desses episódios, contando como revidou o desprezo com que foi tratada por uma balconista:

É, teve um caso aí, no shopping. Que eu fui no Iguatemi e, na época, estava vendendo umas correntinhas. Eu fui perguntar o preço da corrente e a menina falou que eu não tinha dinheiro pra comprar e eu não entendi direito $e$ perguntei de novo. Como eu sou filha de um policial, eu chamei o meu pai, falei pra ele, né? Então o que aconteceu com a mulher foi que ela perdeu o emprego, e eu não dei parte dela porque eu não quero me igualar a ela, eu só quero que ela entenda que eu não sou diferente dela. Então eu, realmente, eu acabei chamando meu pai porque ele já era um policial. Mas eu não dei parte dela, porque só 
Jeitos de corpo

o fato da pessoa ficar sem emprego já é triste... Até ela explicar que ela ficou sem emprego por causa de um racismo, é uma vergonha, então.

As ambivalências dessa narrativa merecem uma análise mais detida. A balconista não tem sua cor revelada, portanto o suposto é que seria branca, reforçado pelo fato de trabalhar numa loja de jóias em um dos mais sofisticados shopping-centers de São Paulo, e agir conforme o estereótipo de arrogância associado a essas trabalhadoras. A garota ofendida, ao invocar a intercessão do pai policial, revida com uma espécie de "você-sabe-comquem-está-falando" (DaMatta, 1979), o ritual restaurador de hierarquias cotidianas, que se espera de pessoas cuja suposta posição especial superior não é devidamente reconhecida em alguma dada ocasião. Embora tenha acarretado sérias consequências para a ofensora (o que nem sempre acontece), esse foi mais um caso de discriminação que teve uma solução privada, como tantos outros no Brasil, pois o policial chamado a restaurar o império da lei é ao mesmo tempo pai da vítima; e a própria garota ressalta que "não quis dar parte", porque a perda do emprego já era um castigo suficiente para a balconista. Além disso, a garota não queria se "igualar" à balconista, isto é, não queria aparecer como alguém que se acha superior aos outros; queria, sim, que a outra percebesse que ela não era "diferente dela"; isto é, que não era "inferior" e merecia ser tratada com o respeito que a balconista devia ter por toda cliente que considerasse sua "igual".

Seja como for, tendo em vista as situações de racismo relatadas, vividas ou não pelas pessoas que as contaram, não surpreende que muitos dos jovens frequentadores do Sambarylove considerem a cor/raça e a definição que fazem dela como algo importante para o modo como se reconhecem e se relacionam com outras pessoas. Nas negociações que fazem com as adversidades da discriminação racial, a estetização se mostrou central: a preocupação de associar determinado estilo de corpo, 
música e dança a ser "negro" ou "negra", como signo de distinção, beleza e simpatia, foi recorrente na fala dos entrevistados. Vários rapazes se apresentaram às pesquisadoras declarando-se ser "negrão simpático", um "negrão gente fina"; e já mencionamos a visão que atribui a erotização dos rapazes negros à estética black. Os jovens frequentadores do Sambarylove provavelmente concordariam com a resposta dada por uma garota à pergunta de como definiria seu estilo: "sou como todo mundo fala: uma pessoa que gosta de andar na pegada, pra aparecer, pra ficar bonito na foto."

Não lhes é estranha, afinal - como também não o é para os rapazes do samba GLS e moças da Gruta -, a percepção de que essas arenas de estilos, apresentações corporais e performances são teatros de desejos e fantasias, por meio das quais se representam e se imaginam, para chegarem a saber quem são, quem podem ser, quem querem ser.

\section{Estilo, música, corpo}

Trazer a uma discussão comparada às narrativas sobre raça, gênero e sexualidade colhidas em espaços de sociabilidade homo $e$ heteroerótica, frequentados por jovens negros e mestiços em São Paulo, deu-nos a possibilidade de chamar a atenção para certas recorrências. Em suas interações de lazer e busca de relacionamentos eróticos e afetivos, esses jovens se deparam com uma série de estigmas, hierarquias, convenções, estereótipos, velhos e novos binarismos (masculino/feminina, negro/branco, ativo/passivo, homo/hetero), seja por conta de cor, corpo, sexo, desejo, postura, atitude, gosto, comportamento, status, classe. Em todos os casos respondem buscando diferentes modos de fazer uso de determinados objetos, práticas e formas expressivas que lhes permitam interferir nos horizontes de imaginação das convenções; ao reinventá-las, de alguma maneira reinventam a si próprios, participando do jogo de demonstrar pertencimentos $e$ compor enunciados pessoais, para se aproximar e se distinguir, 
Jeitos de corpo

dar-se a ver e provocar reações. E não é demais ressaltar os "significantes flutuantes" que continuam centrais nesse repertório: o estilo, mais do que mera embalagem, a própria "matéria do acontecimento", o que "faz acontecer"; a música, do pagode à black music internacionalizada, forma privilegiada de produzir, apreender e expressar experiência; e o corpo, capital cultural singular (quando não o único), a grande tela de representação na qual se investe e se trabalha. ${ }^{28}$

Recorrências, porém, não implicam homogeneidade. Modalidades de racismo, sexismo e homofobia são constitutivas da experiência desses jovens, mas sobressai a variedade das formas de preconceito e discriminação envolvidas. Para além das especificidades históricas e culturais do chamado racismo à brasileira - sempre imputado ao outro e que coexiste com o elogio da mistura e da diversidade de raças e povos - há as articulações singulares de tipos de diferença (com hierarquia) que situam $e$ posicionam os jovens negros e mestiços nas cenas paulistanas de interação e sociabilidade erótica.

Numa cidade em que expressões culturais afro-brasileiras não prevalecem como signos de identidade urbana - e em que o ideal pós-1930 da "nação mestiça" (apesar de Mario de Andrade) não estabeleceu imaginários de pertencimento e acolhimento a negros e mulatos (certamente não como outras capitais brasileiras, como Rio de Janeiro ou Salvador) -, as experiências de racismo aparecem indissociáveis de experiências de marginalização e discriminação por estética, status e classe. Nossos dados sugerem que a polarização negros/brancos é acionada segundo a lógica de uma política de representação que se pratica nas situações cotidianas, na qual "negro" é aquele que é desprezado por ser feio e pobre, tratado como bruto, ignorante, irresponsável, um bandido em potencial. "Negro" também é evocado na compensação desses estigmas por meio de atributos - ginga,

${ }^{28}$ São, afinal, os três elementos centrais do repertório da chamada "cultura popular negra" internacionalizada conforme lembrou Hall (2003:342). 
elegância, criatividade, animação, assim como sedução, sensualidade, potência viril -, que se realizam através da mediação de estilizações corporais e objetos de consumo, que não lidam apenas com binarismos, mas também com interpenetrações e misturas.

A "escola sociológica paulista", como se sabe, argumentou que o preconceito racial era uma resposta estrutural à ameaça que os negros representariam à posição dos brancos em meio à competição social crescente nas áreas em que se organizou uma sociedade capitalista de classes, como São Paulo. Ao circunscrever o tema cor e raça a uma questão de classe, essa escola enfatizou as estratégias de mobilidade social segundo uma lógica de cooptação voltada ao branqueamento, que destruiria sistematicamente as possibilidades de construção de uma identidade negra (Fernandes, 1965). Dessa perspectiva, se construiu uma leitura de denúncia da democracia racial como um mito (no sentido de algo fabricado e falso), dando impulso a uma interpretação concorrente que desestabilizava o que se convenciou chamar de leitura "culturalista" (ou "freyreana") da sociedade brasileira. Hoje em dia, em contrapartida, cultura popular, consumo e erotismo, com suas dimensões míticas e simbólicas, cobram a centralidade que lhes cabe na produção contemporânea de categorias e identidades de cor/raça.

Vimos também que tais categorias e identidades são articuladas e atravessadas por outros eixos de diferenciação, como gênero e sexualidade, participando também de outros arranjos, negociações, acomodações e resistências que complicam as tentativas de fixar alinhamentos e oposições. Como se sabe, a masculinidade positivada do "negão" ou "mano" potente e sedutor se faz à custa não só da vulnerabilidade das mulheres negras e mestiças, mas também da estigmatização da "bichapreta". De outra parte, as fantasias de virilidade da cena black espelham-se nas performances de jovens lésbicas negras $e$ mestiças, abrindo possibilidades de masculinidades alternativas nessa cena, do mesmo modo que as encenações da voluptuosa 
Jeitos de corpo

feminilidade das estrelas black ou das passistas de escola de samba repercutem não só entre lésbicas femininas, mas nos rapazes femininos em suas performances no samba ou no "batecabelo" da drag-music. As relações que o estigma da homossexualidade interdita para rapazes negros de classes populares podem ser compensadas pela construção de novas redes de amizade e afeto no ampliado mercado de sociabilidade $e$ consumo voltado ao público homossexual. Nesses espaços, categorias e performances de gênero operam classificações $e$ hierarquias que abrem possibilidades e constrangimentos diferenciados para a interação erótica e afetiva. A "bicha-preta" é um lugar social que poucos estão dispostos a ocupar, mas com o qual muitos são obrigados a negociar; $e$ alguns podem fazê-lo com disposição e desenvoltura, construindo interações vividas como positivas, não só em termos da sociabilidade homoerótica, mas também em termos de um projeto de vida viável mais amplo. ${ }^{29} \mathrm{O}$ cobiçado papel de "mano" ou "negão", em contrapartida, pode ser vivido como um fardo que aprisiona à condição de objeto de desejo.

De modo geral, esses dados sugerem que os pertencimentos em termos de cor/raça, gênero e sexualidade, mesmo informando uma escala de prestigio e desigualdade, mostram-se também instáveis, contingentes e situacionais. Ao que parece, estamos num terreno de múltiplas retóricas classificatórias, múltiplas negociações e múltiplos agonismos.

\section{Referências bibliográficas}

ABRAMO, Helena. Cenas juvenis: punks e darks no espatáculo urbano. São Paulo, Scritta, 1994.

AguiÃo, Silvia. "Aqui nem todo mundo é igual". Cor, mestiçagem e homossexualidades numa favela do Rio de Janeiro. Dissertação de

${ }^{29}$ Para reflexões semelhantes, abordando modos de circulação social de jovens gays negros e mestiços moradores de uma favela no Rio Janeiro, ver Moutinho (2006) e Aguião (2007). 
Júlio Simões, Isadora França, Marcio Macedo

Mestrado em Saúde Coletiva, Área de Gênero, Sexualidade e Saúde. Rio de Janeiro, IMS/UERJ, 2007.

ANDERSON, Benedict. Comunidades imaginadas. São Paulo, Companhia da Letras, 2008.

AzEVEDO, Thales de. Democracia racial. Petrópolis, Vozes, 1975.

BARBOSA DA SILVA, José Fabio. Homossexualismo em São Paulo: estudo de um grupo minoritário. In: GREEN, James e TRINDADE, Ronaldo. (orgs.) Homossexualismo em São Paulo e outros escritos. São Paulo, Editora da Unesp, 2005, pp .39-212.

BHABHA, Homi. A outra questão: o estereótipo, a discriminação e o discurso do colonialismo. In: .O local da cultura. Belo Horizonte, Ed. da UFMG, 1998, pp. 105-128.

BRAH, Avtar. Diferença, diversidade, diferenciação. Cadernos Pagu (26), Campinas-SP, Núcleo de Estudos de Gênero-Pagu/Unicamp, 2006, pp. 329-376.

CARRARA, Sergio e SIMÕES, Júlio Assis. Sexualidade, cultura e política: a trajetória da identidade homossexual masculina na antropologia brasileira. Cadernos Pagu (28), Campinas-SP, Núcleo de Estudos de Gênero-Pagu/Unicamp, 2007, pp. 65-100.

CRAPANZANO, Vincent. Imaginative horizons: an essay in literaryphilosophical anthropology. Chicago, The University of Chicago Press, 2004.

. Estilos de interpretação e a retórica de categorias sociais. In: MAGGIE, Y e REZENDE, C. (orgs.). Raça como Retórica: a construção da diferença. Rio de Janeiro, Civilização Brasileira, 2002, pp. 441458.

DA MATTA, Roberto. Carnavais, malandros e heróis. Rio de Janeiro, Zahar, 1979.

Deleuze, Gilles e GuATTARI, Felix. O anti-édipo. Rio de Janeiro, Imago, 1976.

ELLINGSON, Stephen et alii. The theory of sex markets. In: LAUMANN. Edward O. et alii. The sexual organization of the city. Chicago, The University of Chicago Press, 2004, pp. 3-38. 
Jeitos de corpo

FACCHINI, Regina. Entre umas e outras: mulheres, homossexualidades e diferenças na cidade de São Paulo. Tese de Doutorado em Ciências Sociais, Área de Estudos de Gênero, IFCH/Unicamp, 2008.

. Sopa de letrinhas? Movimento homossexual e produção de identidades coletivas nos anos 90. Rio de Janeiro, Garamond, 2005.

FERNANDES, Florestan. A integração do negro na sociedade de classes. vol. 2, São Paulo, Dominus, 1965.

FRANÇA, Isadora Lins. Consumindo lugares, consumindo nos lugares: homossexualidade, consumo e subjetividades na cidade de São Paulo. Tese de Doutorado em Ciências Sociais, Área de Estudos de Gênero, IFCH/Unicamp, 2010.

. Na ponta do pé: quando o black, o samba e o GLS se cruzam em São Paulo. In: DiAS BENITEZ, Maria Elvira \& FIGARI, Carlos. (orgs.) Prazeres dissidentes. Rio de Janeiro, CLAM/Garamond, 2009, pp. 393-421.

. Cercas e pontes: o movimento GLBT e o mercado GLS na cidade de São Paulo. Dissertação de Mestrado em Antropologia Social. São Paulo, FFLCH/USP, 2006.

FREYRE, Gilberto. Casa-Grande \& senzala. Rio de Janeiro, Record, 2000 [1933].

FRÚGOLI JR., Heitor. O urbano em questão na antropologia: interfaces com a sociologia. Revista de Antropologia, vol.48, $\mathrm{n}^{\circ} 1,2005$, pp. 133-165. 2000 .

. Centralidade em São Paulo. São Paulo, EDUSP/Cortez,

FRY, Peter. A persistência da raça. Rio de Janeiro, Civilização Brasileira, 2005.

- Da hierarquia à igualdade: a construção histórica da homossexualidade no Brasil. In: FRY, Peter. Para inglês ver: identidade e política na cultura brasileira. Rio de Janeiro, Zahar, 1982, pp.87-115.

GILROY, Paul. Entre campos: nações, cultura e o fascínio da raça. São Paulo, Editora 34, 2007. 
Júlio Simões, Isadora França, Marcio Macedo

O Atlântico negro. São Paulo, Editora 34/UCAM, 2001.

HALL, Stuart. Que "negro" é esse na cultura negra? In: Da diáspora: identidades e mediações culturais. Belo Horizonte, Ed. da UFMG, 2003, pp. 335-349.

. Quem precisa de identidade? In: SILVA, Tomaz Tadeu. (org.) Identidade e diferença. Petrópolis, Vozes, 2000, pp.103-133..

HEBDIGE, Dick. Subculture: the meaning of style. London, Methuen, 1999.

. Hiding in the light. London, Routledge, 1988.

KowARICK, Lucio. (org.) As lutas sociais e a cidade. Rio de Janeiro, Paz e Terra, 1988.

MACEDO, Marcio. Baladas black e rodas de samba da Terra da Garoa. In: MAGNANI, José G. C. e MANTESE, Bruna S. (orgs.) Jovens na Metrópole: etnografias dos circuitos de lazer, encontro e sociabilidade. São Paulo, Editora Terceiro Nome, 2007, pp. 189-224.

MACRAE, Edward. Em defesa do gueto. In: GREEN, James \& TRINDADE, Ronaldo. (orgs.) Homossexualismo em São Paulo e outros escritos. São Paulo, Editora da Unesp, 2005, pp. 291-308.

MARTíINEZ-ECHAZÁBAL, Lourdes. O culturalismo dos anos 30 no Brasil e na América Latina: deslocamento retórico ou conceitual? In: MAIO, Marcos Chor e SANTOS, Ricardo Ventura. (orgs.) Raça, ciência e sociedade. Rio de Janeiro, Fiocruz/CCBB, 1996, pp. 107-124.

MOUTINHO, Laura. Negociando com a adversidade: reflexões sobre "raça", (homos)sexualidade e desigualdade social no Rio de Janeiro. Estudos Feministas, vol. 14, $\mathrm{n}^{\circ}$ 1, Florianópolis-SC, Universidade Federal de Santa Catarina, 2006, pp. 103-116. . Razão, cor e desejo. São Paulo, Editora da Unesp, 2004.

NASCIMENTO, Érica Peçanha. Vozes marginais na literatura. Rio de Janeiro, Aeroplano, 2009.

PERLONGHER, Nestor. O negócio do michê. São Paulo, Editora Fundação Perseu Abramo, 2008. 
Jeitos de corpo

POLLAK, Michel. A homossexualidade masculina, ou: a felicidade no gueto? In: ARIÈs, Philippe et alii. Sexualidades ocidentais. São Paulo, Brasiliense, 1985, pp.54-76.

SAID, Edward. Orientalismo. São Paulo, Companhia das Letras, 2001.

SANSONE, Livio. Negritude sem etnicidade: o local e o global nas relações raciais e na produção cultural negra do Brasil. Salvador/Rio de Janeiro, Edufba/Pallas, 2004.

SCHWARCZ, Lilia. Nem preto nem branco, muito pelo contrário: cor e raça na intimidade In: História da vida privada no Brasil, vol. 4. São Paulo, Companhia das Letras, 2000, pp. 173-244.

SHUKER, Roy. Vocabulário de música pop. São Paulo, Hedra. 1999.

SIMÕES, Julio Assis e FACCHINI, Regina. Na trilha do arco-íris: do movimento homossexual ao LGBT. São Paulo, Editora Fundação Perseu Abramo, 2009.

e FRANÇA, Isadora Lins. Do gueto ao mercado. In: GREEN, James e TRINDADE, Ronaldo. (orgs.) Homossexualismo em São Paulo e outros escritos. São Paulo, Editora da Unesp, 2005, pp. 309-336. 